\title{
PENERAPAN MANAJEMEN PEMBELAJARAN BERBASIS DARİNG DENGAN MENGGUNAKAN APLIKASİ GOOGLE CLASSROOM UNTUK MENINGKATKAN KEMAMPUAN MAHASISWA DALAM MEMBUAT PERANGKAT PEMBELAJARAN
}

\author{
Nafiah $^{1}$, Sri Hartatik ${ }^{2}$ \\ ${ }^{1-2}$ Universitas Nahdlatul Ulama Surabaya \\ 1'nefi_23@unusa.ac.id, ${ }^{2}$ titax@unusa.ac.id
}

\begin{abstract}
Learning-based activities can be done effectively with efficient learning management systems. The aim is to determine the application of online-based learning management by using the google classroom application to improve the ability of students to make learning administration in learning planning in the primary education study program Nahdlatul Ulama University of Surabaya. The research method using classroom action research (CAR) was carried out in primary education study program Nahdlatul Ulama University of Surabaya, thirth semester B class with a total of 56 students. This research method uses classroom action research with four stages, namely planning, action implementation, observation, and reflection. Data collection techniques using checklist and observation. The data analysis technique uses descriptive quantitative. The results showed the application of online-based learning management by using the google classroom application to improve the ability of students to make learning tools in learning planning courses at primary education study program Nahdlatul Ulama University of Surabaya. proved to be very effective in improving the ability of students to compile elementary learning tools. This is seen from the increase in each cycle and the average value of students is more than the specified indicator achievement criteria. In the first cycle to the 1st meeting, the average value of the preparation of elementary school learning administration (Annual program, semester program, syllabus, lesson plan) was around 45, while at the second meeting the average value of the learning equipment was around 68.25 . Whereas in the second cycle at the 1st meeting the average value of the preparation of learning devices was around 73.5, whereas at the second meeting the average value of students in the preparation of the elementary learning tools was 96.75.
\end{abstract}

Keywords: Learning Management, google classroom, Learning planning

\begin{abstract}
Abstrak: Kegiatan pembelajaran berbasiskan dapat dilakukan dengan efektif efesien jika dilakukan sistem manajemen pembelajaran dengan baik. Tujuan penelitian ini untuk mengetahui penerapan manajemen pembelajaran berbasis daring dengan menggunakan aplikasi google classroom untuk meningkatkan kemampuan mahasiswa dalam membuat perangkat pembelajaran pada mata kuliah perencanaan pembelajaran di Prodi S1 PGSD FKIP UNUSA. Metode penelitian menggunakan penelitian tindakan kelas (PTK), penelitian ini dilaksanakan di prodi PGSD FKIP UNUSA semester 3 kelas B dengan jumlah mahasiswa 56 mahasiswa. Penelitian ini tergolong penelitian tindakan kelas dengan empat tahap yaitu perencanaan, pelaksanaan tindakan, observasi, dan refleksi. Teknik pengumpulan data dengan menggunakan ceklist (checklist) dan lembar observasi. Teknik analisis data menggunakan kuantitatif deskriptif. Hasil penelitian menunjukkan bahwa penerapan manajemen pembelajaran berbasis daring dengan menggunakan aplikasi google classroom dapat meningkatkan kemampuan mahasiswa dalam membuat perangkat pembelajaran pada mata kuliah perencanaan pembelajaran di Prodi S1 PGSD FKIP UNUSA. Hal tersebut dilihat dari kenaikan rata-rata nilai setiap siklus dan nilai rata-rata mahasiswa lebih dari kriteria ketercapaian indikator yang ditentukan. Pada siklus 1 pertemuan ke 1 rata-rata nilai penyusunan perangkat pembelajaran SD (Prota, Prosem/Promes, Silabus, RPP) sekitar 45, sedangkan pada pertemuan ke 2 nilai rata-rata peragkat pembelajaran sekitar 68,25 . Pada siklus ke 2 pada pertemuan 1 nilai rata-rata penyusunan perangkat pembelajaran sekitar 73,5 , sedangkan pada pertemuan ke 2 nilai rata-rata mahasiswa dalam penyususnan perangkat pembelajaran SD sebesar 96,75.
\end{abstract}

Kata kunci: Manajememen Pembelajaran, google classroom, Perencanaan pembelajaran 


\section{PENDAHULUAN}

Era revolusi industry 4.0 ditandai dengan penggunaan jaringan internet sebagai tulang punggung pergerakan dan konektivitas manusia dan mesin. Perkembangan ilmu pengetahuan dan teknologi saat ini mengalami peningkatan yang sangat signifikan terutama pada bidang teknologi untuk memenuhi kebutuhan sehari-hari. Hasil survei dari Asosiasi Penyelenggara Jaringan Internet Indonesia pada tahun 2019 pengguna internet di Indonesia menyebutkan bahwa jumlah pengguna internet di indonesia tembus 171 juta jiwa atau sekitar 64,8 persen dari total populasi sebanyak 264 juta jiwa penduduk Indonesia yang sudah terhubung ke internet (Pratomo, 2019). Penggunaan internet memiliki dampak positif apabila digunakan untuk mendukung kegiatan pembelajaran.

Kegiatan pembelajaran berbasis internet dapat dilakukan dengan efektif efesien melalui sistem manajemen pembelajaran. Learning management system is an important tool for the development of curriculum design, management of students' learning and their motivation to learn (Meenakumari \& Antony, 2013). Sistem manajemen pembelajaran alat yang sangat penting untuk mengembangkan desan kurikulum, manajemen pembelajaran siswa dan motivasi siswa untuk belajar.

Sistem manajemen pembelajaran merupakan suatu manajemen pembelajaran yang disiapkan untuk mahasiswa/siswa dan dosen/guru dalam melakukan pembelajaran melalui perangkat lunak. Adapun perangkat lunak sistem manajemen pemyang bisa digunakan salah satunya dalah google classroom (Wicaksono \& Rachmadyanti, 2017:514). Pada tahap awal di tahun 2014-2016 pengembangan google classroom tidak diperuntukan untuk semua orang hanya sekolah yang berkerjasama dengan google, namun di bulan Maret 2017 google classroom dapat diakses oleh seluruh orang dengan menggunakan google pribadi. Hal ini yang dapat dimanfaatkan oleh dosen, guru, siswa dan mahasiswa dalam pembelajaran, sehingga tidak diperlukan kerjasama dengan google. Pemanfaatan secara terbuka dapat memberikan keuntungan bagi pengguna google classroom (Wicaksono \& Rachmadyanti, 2017:516-517). Penggunaan google classroom juga dapat digunakan dalam kegiatan perkuliahan, dosen dapat memanfaatkan google classroom untuk melakukan perkuliahan secara daring dengan mahasiswa.

Google classroom merupakan sebuah aplikasi yang memungkinkan terciptanya ruang kelas di dunia maya. Selain itu, google classroom dapat dijadikan sarana pembelajaran untuk mengumpulkan tugas, menilai tugas bahkan menilai tugas-tugas yang dikumpulkan. Dengan demikian, aplikasi ini dapat membantu memudahkan guru / dosen dan siswa/ mahasiswa dalam melaksanakan proses belajar dengan lebih mendalam (Putri \& Dewi, 2019). Penggunaan google classroom mempemudah dosen untuk memeriksa hasil tugas mahasiswa dan dapat memberikan nilai secara langsung pada mahasiswa.

Adapun kelebihan google classroom yakni mudah digunakan, menghemat waktu, berbasis cloud, fleksibel, dan gratis. Hal ini yang menjadi pertimbangan bahwa google classroom tepat digunakan dalam pembelajaran. Penggunaan google classroom ini sesungguhnya mempermudah guru/dosen dalam mengelola atau memanajemen pembelajaran serta menyampaikan informasi siswa/mahasiswa (Maharani \& Kartini, 2019). Manajemen pembelajaran berbasis daring dengan menggunakan google classroom dapat memermudah dosen dalam mengelola kegiatan perkuliahan secara efektif efesien.

Manajemen merupakan kemampuan dan keterampilan khusus yang dimiliki oleh seseorang untuk melakukan suatu kegiatan baik secara perorangan ataupun bersama orang lain ataumelalui orang lain dalam upaya mencapai tujuan rganisasi secara produktif, efektif dan efesien (Nafiah, 2017). Manajemen pembelajaran merupakan 
kemampuan dalam mengelola secara operasional dan efesien terhadap komponenkomponen yang berkitan dengan pembelajaran, sehingga menghasilkan nilai tambah terhadap komponen tersebut menurut norma/standar yang berlaku (Yamin \& Maisah, 2012).

Proses manajemen pembelajaran adalah perencanaan pembelajaran, pelaksanaan pembelajaran, dan evaluasi pembelajaran. Sebagai perencana pembelajaran, guru maupun dosen dapat melakukan diagnosa untuk kebutuhan siswa maupun mahasiswa sebagai subjek dalam pembelajaran di kelas. Guru/dosen dapat merumuskan tujuan pembelajaran, menetapkan metode pembelajaran, dan melaksanakan pembelajaran sesuai dengan tujuan pembelajaran yang ditetapkan (Nafiah, 2017). Perencanaan itu dapat bermanfaat bagi guru sebagai kontrol terhadap diri sendiri agar dapat memperbaiki pembelajaran yang dilakukan guru/dosen. Pada kegiatan pembelajaran, dilakukan pengelolaan dan kepemimpinan pembelajaran di kelas serta melakukan pengelolaan peserta didik. Pada evaluasi pembelajaran dilakukan untuk menentukan mutu pembelajaran secara menyeluruh.

Menurut Majid (2008), terdapat beberapa manfaat perencanaan pembelajaran adalah sebagai petunjuk arah kegiatan pembelajaran dalam pencapaian tujuan, sebagai pola dasar dalam mengatur tugas pada kegiatan pembelajaran, sebagai pedoman kerja bagi guru/dosen maupun siswa/mahasiswa, sebagai alat ukur efektif tidaknya suatu kegiatan pembelajaran yang dilakukan guru/dosen, sebagai penyusunan data agar terjadi kesinambungan kerja dalam melakukan perbaikan proses pembelajaran, agar menghemat waktu, tenaga, alat-alat dan biaya.

Menurut Uno (Uno, 2008), perlunya perencanaan pembelajaran dimaksudkan agar dapat dicapai perbaikan pembelajaran. Upaya perbaikan pembelajaran ini dilakukan dengan melakukan perbaikan kualitas pembelajaran, untuk merancang sistem dalam suatu pembelajaran dengan menggunakan pendekatan sistem, merancang desain pembelajaran sesuai siswa per individu, untuk mencapai tujuan pembelajaran, agar memudahkan siswa/mahasiswa untuk belajar, untuk menetapkan strategi dan metode pembelajaran yang akan digunakan..

Pengelolaan kelas adalah kegiatan mengatur sejumlah sumber daya yang ada di kelas sehingga dapat mencapai tujuan pembelajaran yang ingin dicapai secara efektif dan efisien. Kegiatan pengaturan sumber daya yang dilakukan di kelas mencakup unsure manusia dan non manusia, kedua unsure tersebut memiliki kedudukan yang sangat penting guna mendukung tercapainya tujuan pembelajaran yang dikehendaki.

Penggunaan Google classroom dirancang untuk memudahkan dosen berinteraksi dengan mahasiswa. Aplikasi ini memberikan kesempatan kepada para dosen atau guru untuk mengeksplorasi gagasan yang dimilikinya kepada mahasiswa (Albantani \& Rozak, 2018).

Peggunaan google classroom dapat membantu mahasiswa dan dosen menuju sistem paperless. Pembuatan tugas belajar dan distribusi materi dilakukan melalui google drive sementara Gmail digunakan untuk menyediakan komunikasi kelas. Mahasiswa bisa diajak berinteraksi dalam ruang kelas melalui database lembaga atau melalui kode pribadi yang kemudian dapat ditambahkan mahasiswa yang masuk pada setiap kelas. Setiap kelas yang dibuat dengan Google Kelas menciptakan folder terpisah di produk Google masingmasing di mana mahasiswa dapat mengirimkan pekerjaan yang harus dinilai oleh dosen (Kurniawan, 2016:61). Komunikasi melalui google classroom memungkinkan dosen untuk membuat memberikan materi kuliah, memberikan tugas kuliah dan diskusi di setiap kelas. 
The most important findings emphasize the fact that students prefer the engagement in Google classroom where the teachers have passive roles rather than being engaged in a class where the teachers have more active roles (Al-Maroof \& Al-Emran, 2018).

Pengaplikasian Google Classroom sangat mudah untuk digunakan dalam kegiatan pembelajaran. Aplikasi Google Classroom ini dapat diunduh secara gratis. Ada beberapa fitur yang ada pada Google Classroom yaitu assignments, grading, communication, timecost, archive course, mobile application dan privacy (Maharani \& Kartini, 2019). Manfaat Google Classroom adalah: 1) mempermudah pengajar (guru, dosen) dalam menyiapkan pembelajaran dengan menambahkan siswa dalam kelas atau membagikan kode kelas pada siswa, 2) lebih menghemat waktu, alur tugas yang sederhana dan tanpa kertas memungkinkan dosen/guru membuat, memeriksa, dan menilai tugas dengan cepat, di satu tempat, 3) meningkatkan pengorganisasian mahasiswa dapat melihat semua tugasnya di laman tugas, dan semua materi kelas secara otomatis disimpan ke dalam folder di google drive, 4) meningkatkan komunikasi kelas memungkinkan pengajar untuk mengirim pengumuman dan memulai diskusi secara langsung. Mahasiswa dapat berbagi sumber daya satu sama lain atau memberikan jawaban atas pertanyaan di aplikasi google classroom (Putri \& Dewi, 2019). Aplikasi ini cocok digunakan untuk kegiatan pembelajaran bagi mahasiswa. Salah satu prodi yang menggunakan aplikasi ini adalah program studi pendidikan guru sekolah dasar pada mata kuliah perencanaan pembelajaran. Agar calon guru menguasai kompetensi pedagogik, salah satu indikatornya adalah dapat meyusun perangkat pembelajaran SD dengan baik maka mahasiswa diberikan mata kuliah perencanaan pembelajaran. Pada mata kuliah tersebut, mahasiswa diajarkan cara menyususn perangkat pembelajaran SD

Perencanaan merupakan upaya membuat kegiatan agar lebih fokus dan terarah. Perencanaan adalah menyusun langkah-langkah penyelesaian suatu masalah atau pelaksanaan suatu pekerjaan yang terarah pada pencapaian tujuan tertentu (Sholeh, 2007). Perencanaan mencakup kegiatan pengambilan keputusan. Untuk itu diperlukan kemampuan untuk mengadakan visualisasi dan melihat ke depan guna merumuskan suatu pola tindakan untuk masa mendatang. Perencanaan adalah awal dari semua proses yang rasional dan mengandung sifat optimisme yang didasarkan atas kepercayaan bahwa akan dapatvmengatasi berbagai macam permasalahan. Perencanaan didefinisikan dalam bernagai macam ragam tergantung dari sudut pandang mana melihat, serta latar belakang apa yang mempengaruhi orang tersebut dalam merumuskan definisi.

Perencanaan diartikan sebagai proses proses serangkaian kebijakan untuk mengendalikan masa depan. Perencanaan pembelajaran meliputi penyusunan rencana pelaksanaan pembelajaran (RPP), penyiapan media dan sumber belajar, perencanaan penilaian pembelajaran, penyusunan rencana pelaksanaan pembelajaran, skenario pembelajaran, dan penyiapan media dan sumber belajar, perangkat penilaian pembelajaran (Nadlir, 2013). Perencanaan pembelajaran dapat diartikan proses penyusunan materi pelajaran, penggunaan media pengajaran, penggunaan pendekatan dan metode pengajaran dan peilaian dalam suatu alokasi waktu yang akan dilaksanakan pada masa tertentu untuk mencapai tujuan yang elah direncanakan.

Perencanaan pembelajaran memainkan peran penting dalam tugas sebagai guru/dosen untuk melayani kebutuhan belajar siswa/mahasiswa. Perencanaan pembelajaran merupakan langkah awal sebelum melakukan kegiatan pembelajaran. Manfaat perencanaan pembelajaran adalah sebagai berikut: sebagai pola dasar dalam mengatur tugas dan wewenang bagi setiap unsur yang terlibat dalam kegiatan, sebagai pedoman kerja bagi setiap unsur, baik unsur guru maupun unsur murid, sebagai alat ukur 
efektif tidaknya suatu pekerjaan sehingga setiap saat bisa diketahui ketepatan dan kelambatan kerja, untuk bahan penyusunan data agar terjadi keseimbangan kerja, untuk menghemat waktu, tenaga alat-alat dan biaya.

Mata kuliah ini dimaksudkan untuk membekali mahasiswa agar memiliki pengetahuan dan pemahaman tentang perencanaan pembelajaran. Mata kuliah ini difokuskan pada materi yang berkaitan dengan konsep dasar perencanaan pembelajaran dan pengembangan perencanaan pembelajaran yang meliputi: Perencanaan beban belajar, kalender pendidikan dan rincian minggu efektif, perencanaan program tahunan, perencanaan program semester, pengembangan persiapan mengajar, pengembangan silabus, pengembangan bahan ajar, dan pengembangan rencana pelaksanaan pembelajaran.

Mahasiswa dapat menguasai dan mengembangkan perencanaan pembelajaran di tingkat sekolah dasar yang meliputi perencanaan beban belajar, kalender pendidikan dan rincian minggu efektif, perencanaan program tahunan, perencanaan program semester, pengembangan persiapan mengajar, pengembangan silabus, pengembangan bahan ajar, dan pengembangan rencana pelaksanaan pembelajaran dengan tepat.

Melalui mata kuliah ini mahasiswa dapat menguasai, dan mampu mengimplementasikan konsep dasar perencanaan pembelajaran dan kurikulum sekolah serta pengembangan perencanaan pembelajaran yang meliputi: Perencanaan beban belajar, kalender pendidikan dan rincian minggu efektif, perencanaan program tahunan, perencanaan program semester, pengembangan persiapan mengajar, pengembangan silabus, pengembangan bahan ajar, dan pengembangan rencana pelaksanaan pembelajaran.

Setelah mengikuti mata kuliah ini, mahasiswa mampu menguasai dan dapat mengiplementasikan perencanaan pembelajaran yang meliputi Perencanaan beban belajar, kalender pendidikan dan rincian minggu efektif, perencanaan program tahunan, perencanaan program semester, pengembangan persiapan mengajar, pengembangan silabus, pengembangan bahan ajar, dan pengembangan rencana pelaksanaan pembelajaran.

Mengacu pada permasalahan di atas, tujuan penelitian ini adalah untuk mengetahui penerapan manajemen pembelajaran berbasis daring dengan menggunakan aplikasi google classroom untuk meningkatkan kemampuan mahasiswa dalam membuat perangkat pembelajaran pada mata kuliah perencanaan pembelajaran di Prodi S1 PGSD FKIP UNUSA.

Hipotesis penelitian tindakan pada artikel ini adalah penerapan manajemen pembelajaran berbasis daring dengan menggunakan aplikasi google classroom dapat meningkatkan kemampuan mahasiswa dalam membuat perangkat pembelajaran pada mata kuliah perencanaan pembelajaran di Prodi S1 PGSD FKIP UNUSA

\section{METODE}

Penelitian ini menggunakan penelitian tindakan (action reseach). Tujuan peelitian tindakan adalah untuk meningkatkan praktek pendidikan berdasarkan masalah yang dihadapi.

The purpose of action reseach to improve the practice of education by studying issues or problems they face. Educators reflect about these problems, collect and analyze data, and implement changes based on their finding's action research designs are systematic procedures done by teachers (or other individuals in an educational setting) to gather 
information about, and subsequently improve, the ways their particular educational setting operates, their teaching, and their student learning (Creswell, 2012)

Guru melakukan refeksi terhadap pembelajaran yang telah dilakukan, mengumpulkan dan menganalisis dan melaksanakan perubahan berdasarkan temuan di kelas, melaksanakan penelitian tindakan sesuai dengan langkah-langkah penelitian tindakan untuk memecahkan permasalahan yang dihadapi guru di kelas. Jenis penelitian tindakan adalah penelitian tindakan kelas. Tujuan dari Penelitian Tindakan Kelas ini yaitu untuk memperbaiki dan atau meningkatkan praktik proses pembelajaran di kelas.

Dalam penelitian ini peneliti menggunakan Model Kemmis dan Mc Taggart yang setiap siklus terdiri dari empat komponen tindakan yaitu perencanaan, pelaksanaan tindakan, observasi dan refleksi. Penelitian ini dilakukan dengan menggunakan model penelitian dari Kemmis dan Mc. Taggart karena model tersebut sesuai dengan rencana penelitian yang akan dilakukan. Rencana penelitian tersebut yaitu diawali dengan observasi masalah pembelajaran yang terjadi di mata kuliah perencanaan pembelajaran di prodi S1 PGSD FKIP UNUSA dan dilanjutkan dengan merencanakan tindakan yang akan dilakukan untuk menghadapi masalah tersebut. Rencana tindakan tersebut dilanjutkan dengan menerapkan tindakan yang sudah direncanakan serta mengamati rencana tindakan yang sudah diterapkan.Siklus ini diakhiri dengan refleksi.

Penelitian ini dilaksanakan pada mata kuliah perencanaan pembelajaran di prodi S1 PGSD FKIP UNUSA. Adapun waktu pelaksanaannya pada bulan September-November tahun 2019. Subjek dalam penelitian ini adalah mahasiswa mata kuliah perencanaan pembelajaran di prodi S1 PGSD FKIP UNUSA tahun akademik dengan jumlah 55 mahasiswa.

Teknik pengumpulan data yang digunakan dalam penelitian ini adalah checklist dan observasi. Teknik analisis data yang digunakan adalah kuantitatif deskriptif yaitu menggambarkan berapa banyak mahasiswa yang telah menyelesaikan produk perangkat pembelajaran secara benar, apakah ada peningkatan dan apabila kemampuan menyususn perangkat pembelajaran SD dikatakan meningkat jika 75\% mahasiswa telah menyelesaikan semua tugas menyusun perangkat pembelajaran dengan benar.

\section{HASIL}

Peneliti memperoleh data hasil penelitian dari hasil 2 siklus penelitian. Berdasarkan kedua siklus penelitian, semuanya menerapkan manajemen pembelajaran berbasis daring dengan menggunakan aplikasi google classroom untuk meningkatkan kemampuan mahasiswa dalam membuat perangkat pembelajaran. Pada siklus I penggunaan aplikasi google classroom dilakukan secara kelompok sedangkan pada siklus II penggunaan aplikasi google classroom dilakukan secara individu. Kedua siklus penelitian tersebut dilaksanakan di prodi S1 PGSD FKIP UNUSA pada mata kuliah perencanaan pembelajaran dengan jumlah mahasiswa kelas A sebanyak 55 orang yang pada penyusunan perangkat pembelajaran sekolah dasar.

Penelitian tindakan kelas ini dilaksanakan dalam 2 siklus, masing-masing siklus terdapat 4 tahapan, yaitu perencanaan, pelaksanaan, pengamatan, dan refleksi. Siklus I dan siklus II terdiri dari dua pertemuan. Kegiatan pembelajaran dilaksanakan sesuai dengan jadwal perkuliahan perencanaan pembelajaran dengan alokasi waktu setiap tatap muka 150 menit. Hasil penelitian tindakan kelas yang terdiri dari dua siklus yaitu siklus I dan siklus II dengan menerapkan manajemen pembelajaran berbasis daring dengan menggunakan aplikasi google classroom adalah sebagai berikut. 


\section{Siklus 1}

Dalam melakukan penelitian tindakan kelas, peneliti memiliki empat tahapan proses kegiatan pembelajaran pada siklus I yakni yang terdiri dari 4 tahapan, yaitu tahap perencanaan, tahap pelaksanaan, tahap pengamatan, dan tahap refleksi. Rincian keempat tahapan tersebut adalah sebagai berikut:

1. Perencanaan (Planning)

Sebelum melakukan penelitian tindakan kelas, peneliti terlebih dahulu melaksanakan tahap perencanaan. Tahap perencanaan ini dimulai dari peneliti mengajukan permohonan izin kepada kaprodi PGSD dan dekan FKIP UNUSA. Kemudian peneliti bekerja sama dengan tim peneliti melakukan penemuan masalah yang terjadi di kelas dan merancang tindakan yang akan dilakukan, seperti: menyusun RPS dan rencana pelaksanaan pembelajaran (RPP), membuat aplikasi google classroom mata kuliah perencanaan pembelajaran, mengupload semua materi perencanaan pembelajaran pada google classroom, meminta mahasiswa mendownload google classroom pada play store yang ada di HP, jika membuka leptop, peneliti meminta klik alamat www.classroom.google.com, membagikan kode kelas mata kuliah perencanaan pembelajaran pada mahasiswa kelas A prodi S1 PGSD FKIP UNUSA, berikut ini kelas A mata kuliah perencanaan pembelajaran dan kode kelas yang akan di bagikan pada mahasiswa. Setelah membagikan kode kelas pada semua mahasiswa, maka mahasiswa akan masuk pada kelas mata kuliah kita. Jumlah mahasiswa mata kuliah perencanaan kelas A sebanyak 55 mahasiswa.

\section{Pelaksanaan (Acting)}

Setelah melalui tahap perencanaan, peneliti melaksanakan pada tahapan yang kedua yakni pada tahap pelaksanaan. Dalam tahap pelaksanaan ini rancangan dan skenario pembelajaran yang sudah disiapkan oleh pelaksana diterapkan di dalam kelas. Selama proses pembelajaran berlangsung peneliti dibantu oleh tim peneliti untuk sebagai pengamat untuk mengamati mahasiswa. Setelah proses pembelajaran dilakukan evaluasi dengan menggunaan aplikasi google classroom yang telah disiapkan oleh peneliti pada tahap perencanaan.

a. Pembelajaran Siklus I Pada Pertemuan 1

Materi yang dipelajari pada pertemuan pertama adalah menyusun silabus SD sesuai kurikulum 2013 untuk pelajaran tematik kelas menjadi 12 kelompok, untuk mengerjakan kelas 1 semester gasal, kelas 1 semester genap, kelas 2 semester gasal, kelas 2 semester genap, kelas 3 semester gasal, kelas 3 semester genap, kelas 4 semester gasal, kelas 4 semester genap, kelas 5 semester gasal, kelas 5 semester genap, kelas 6 semester gasal, kelas 6 semester genap. Kemudian masing-masing kelompok diminta oleh dosen untuk mengupload hasil pekerjaannya pada google classroom secara mandiri pada penugasan yang telah di berikan, untuk menyusun silabus. Berikut merupakan penugasan yang harus dikerjakan mahasiswa dalam aplikasi google classroom:

\section{b. Pembelajaran Siklus I Pada Pertemuan 2}

Materi yang dipelajari pada pertemua ke 2 adalah bagaimana menyusun silabus SD sesuai kurikulum 2013. Pada pertemuan ini, peneliti meminta semua mahasiswa presentasi terhadap silabus yang telah dikerjakan dan mengoreksi silabus yang telah di buat.. Berdasarkan hasil penugasan pada pertemuan kedua, ternyata ada peningkatan pemahaman mahasiswa terhadap penguasaan silabus SD dan meminta merevisi hasil tugas yang telah dikerjakan dan mengupload kembali pada google 
classroom, jumlah mahasiswa yang menggmpulkan tugas sebesar $60 \%$ dari jumlah mahasiswa. Berdasarkan hasil rekapitulasi siklus 1 pertemuan 1 dan ke 2 diperoleh data sebagai berikut:

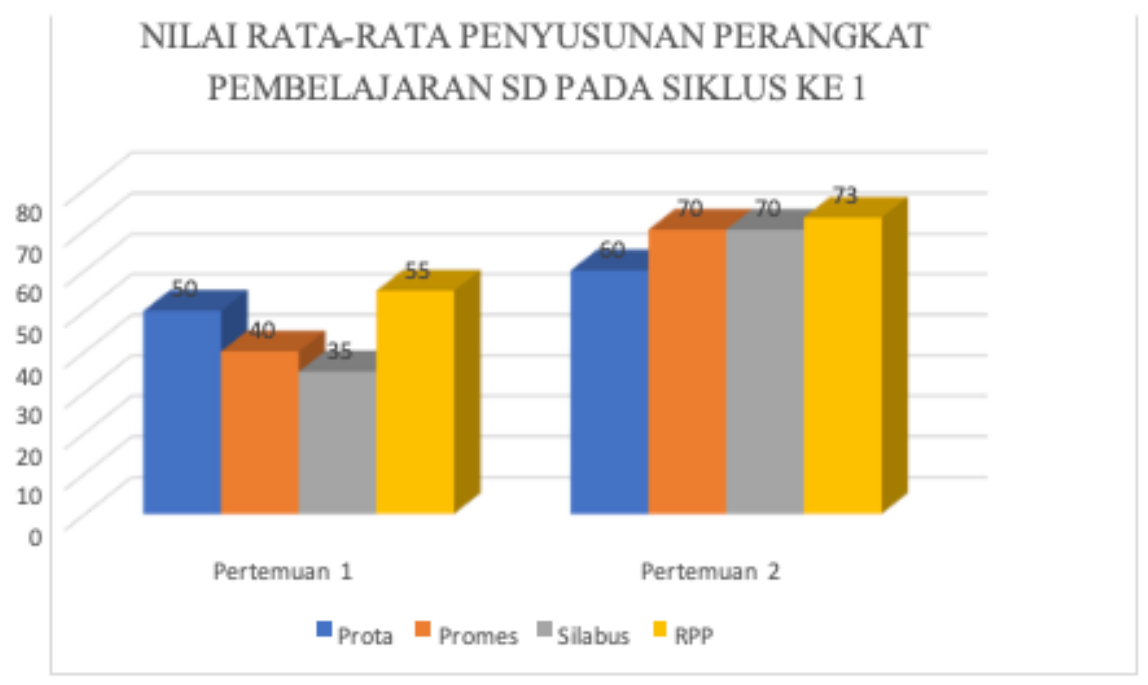

Gambar 1 Rekapitulasi Hasil Siklus 1

Berdasarkan Gambar 2 menunjukkan bahwa nilai rata-rata penyusunan perangkat pembelajaran pada siklus ke 1 pertemuan ke 1, nilai rata-rata mahasiswa dalam menyusun prota sebesar 50, sedangkan prosem/promes sebesar 40, penyusunan silabus sebesar 35 dan penyusunan RPP sebesar 55. Sedangkan pada siklus ke 2 pertemuan ke 2 adalah, nilai rata-rata mahasiswa dalam menyusun prota sebesar 60 , sedangkan prosem/promes sebesar 70 , penyusunan silabus sebesar 70 dan penyusunan RPP sebesar 73.

\section{c. Pengamatan (Observing)}

Pada tahap pengamatan dilakukan bersamaan pada saat proses pembelajaran berlangsung. Peneliti melakukan pengamatan dan mencatat semua hal-hal yang terjadi dan atau yang berkaitan dengan proses pembelajaran saat penelitian tindakan berlangsung. Sehingga dapat mengetahui proses pembelajaran yang dilaksanakan sesuai dengan rancangan dan skenario yang telah dibuat. Dan dilaksanakan evaluasi dengan tujuan untuk mengetahui tingkat ketercapaian siswa yang diharapkan pada pembelajaran tersebut.

\section{d. Refleksi}

Dalam tahap refleksi ada kegiatan akhir yang dilakukan yaitu mengkaji secara menyeluruh tindakan yang telah dilakukan yang meliputi analisis, evaluasi, dan mendiskusikan data yang telah diperoleh. Apabila terdapat masalah atau belum mencapai tujuan yang diharapkan maka dilakukan proses pengkajian atau perbaikan dan diterapkan pada siklus selanjutnya.

Nilai rata-rata penyusunan perangkat pembelajaran pada siklus ke 1 pertemuan ke 1, nilai rata-rata mahasiswa dalam menyusun prota sebesar 50, sedangkan prosem/promes sebesar 40, penyusunan silabus sebesar 35 dan penyusunan RPP sebesar 55. Sedangkan pada siklus ke 2 pertemuan ke 2 adalah, nilai rata-rata 
mahasiswa dalam menyusun prota sebesar 60 , sedangkan prosem/promes sebesar 70 , penyusunan silabus sebesar 70 dan penyusunan RPP sebesar 73.

Dengan demikian, maka akan dilakukan perbaikan dalam pelaksanaan proses pembelajaran pada siklus II agar kemampuan mahasiswa dalam menyususn perangkat pembelajaran SD sesuai kurikulum 2013 meningkat. Hal-hal yang perlu dilakukan untuk memperbaiki proses pembelajaran pada siklus berikutnya antara lain dengan cara: a) Memberikan arahan kepada mahasiswa yakni dengan memberi penjelasan ulang kepada mahasiswa secara klasikal mengenai penyususnan silabus, b) memberikan batas waktu end date untuk mengupload semua tugas yang pada google classroom.

\section{Siklus 2}

Dalam melakukan penelitian tindakan kelas, peneliti memiliki empat tahapan proses kegiatan pembelajaran pada siklus II yang sama seperti pada siklus I yakni yang terdiri dari 4 tahapan, yaitu tahap perencanaan, tahap pelaksanaan, tahap pengamatan, dan tahap refleksi. Rincian keempat tahapan tersebut adalah sebagai berikut:

\section{Perencanaan (Planning)}

Pada tahap perencanaan siklus II ini dimulai peneliti bekerja sama dengan tim peneliti melakukan perbaikan untuk memecahkan masalah yang terjadi di kelas dan merancang tindakan yang akan dilakukan, seperti: Peneliti menyusun RPS dan rencana pelaksanaan pembelajaran (RPP), peneliti menyiapkan format lembar kerja mahasiswa, menyiapkan materi yang akan disampaikan pada mahasiswa

\section{Pelaksanaan (Acting)}

Setelah melalui tahap perencanaan, peneliti melaksanakan pada tahapan yang kedua yakni pada tahap pelaksanaan. Dalam tahap pelaksanaan ini rancangan dan skenario pembelajaran yang sudah disiapkan oleh pelaksana diterapkan di dalam kelas. Selama proses pembelajaran berlangsung peneliti dibantu oleh tim peneliti untuk sebagai pengamat untuk mengamati mahasiswa. Setelah proses pembelajaran dilakukan evaluasi dengan menggunaan aplikasi google classroom yang telah disiapkan oleh peneliti pada tahap perencanaan.

\section{a. Pembelajaran Siklus I Pada Pertemuan 1}

Materi yang dipelajari pada pertemuan pertama adalah review silabus dan menyusun RPP SD sesuai kurikulum 2013 untuk pelajaran tematik kelas menjadi 12 kelompok, untuk mengerjakan kelas 1 semester gasal, kelas 1 semester genap, kelas 2 semester gasal, kelas 2 semester genap, kelas 3 semester gasal, kelas 3 semester genap, kelas 4 semester gasal, kelas 4 semester genap, kelas 5 semester gasal, kelas 5 semester genap, kelas 6 semester gasal, kelas 6 semester genap. Kemudian masing-masing kelompok diminta oleh dosen untuk mengupload hasil pekerjaannya pada google classroom secara mandiri pada penugasan yang telah di berikan, untuk menyusun RPP SD. Berdasarkan hasil penugasan pada pertemuan pertama, jumlah mahasiswa yang menggmpulkan tugas silabus mencapai 98,18\% sedangkan yang mengumpulkan RPP sebesar $40 \%$ dari jumlah mahasiswa.

b. Pembelajaran Siklus I Pada Pertemuan 2 
Materi yang dipelajari pada pertemua ke 2 adalah bagaimana menyusun RPP SD sesuai kurikulum 2013. Pada pertemuan ini, peneliti meminta semua mahasiswa presentasi terhadap RPP yang telah dikerjakan dan mengoreksi RPP yang telah di buat.. Berdasarkan hasil penugasan pada pertemuan kedua, ternyata ada peningkatan pemahaman mahasiswa terhadap penguasaan silabus SD dan meminta merevisi hasil tugas yang telah dikerjakan dan mengupload kembali pada google classroom, jumlah mahasiswa yang menggmpulkan tugas sebesar 98,1\% dari jumlah mahasiswa. Berdasarkan hasil rekapitulasi siklus 1 pertemuan 1 dan ke 2 diperoleh data sebagai berikut:

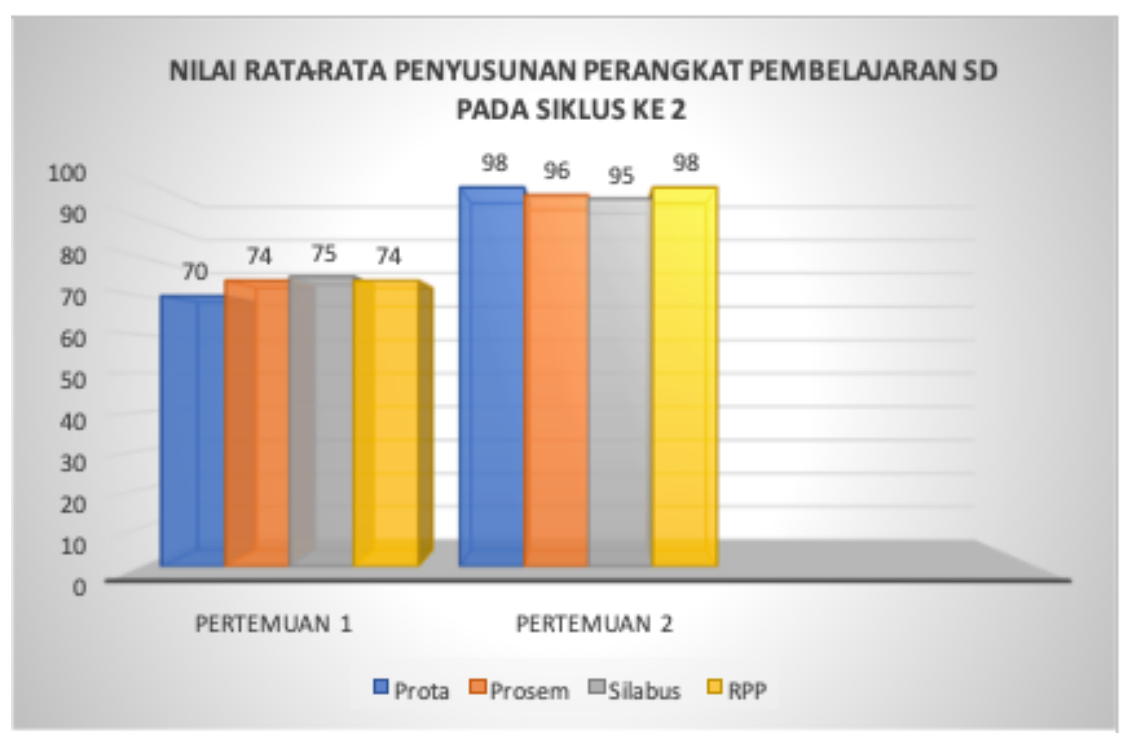

Gambar 2 Rekapitulasi Hasil Siklus 2

Berdasarkan gambar 4.2 menunjukkan bahwa nilai rata-rata penyusunan perangkat pembelajaran pada siklus ke 2 pertemua ke 1, nilai rata-rata mahasiswa dalam menyusun prota sebesar 70 , sedangkan prosem/promes sebesar 74 , penyusunan silabus sebesar 75 dan penyusunan RPP sebesar 74. Sedangkan pada siklus ke 2 pertemuan ke 2 adalah, nilai rata-rata mahasiswa dalam menyusun prota sebesar 98 , sedangkan prosem/promes sebesar 96, penyusunan silabus sebesar 95 dan penyusunan RPP sebesar 98.

\section{Pengamatan (Observing)}

Pada tahap pengamatan dilakukan bersamaan pada saat proses pembelajaran berlangsung. Peneliti melakukan pengamatan dan mencatat semua hal-hal yang terjadi dan atau yang berkaitan dengan proses pembelajaran saat penelitian tindakan berlangsung. Sehingga dapat mengetahui proses pembelajaran yang dilaksanakan sesuai dengan rancangan dan skenario yang telah dibuat. Dan dilaksanakan evaluasi dengan tujuan untuk mengetahui tingkat ketercapaian siswa yang diharapkan pada pembelajaran tersebut. Pada siklus ke 2 pertemuan ke 1 dan ke 2 mahasiswa sudah dapat mengerjakan perangkat pembelajaran SD dengan benar dan dikupulkan semua pada google classroom, dari 55 mahasiswa yang tidak mengumpulkan hanya ada 1 
mahasiswa, karena dari awal mahasiswa tersebut tidak jarang mengikuti perkulihan perencanaan pembelajaran.

\section{Refleksi}

Dalam tahap refleksi ada kegiatan akhir yang dilakukan yaitu mengkaji secara menyeluruh tindakan yang telah dilakukan yang meliputi analisis, evaluasi, dan mendiskusikan data yang telah diperoleh. Apabila terdapat masalah atau belum mencapai tujuan yang diharapkan maka dilakukan proses pengkajian atau perbaikan dan diterapkan pada siklus selanjutnya.

Nilai rata-rata penyusunan perangkat pembelajaran pada siklus ke 2 pertemuan ke 1, nilai rata-rata mahasiswa dalam menyusun prota sebesar 70 , sedangkan prosem/promes sebesar 74 , penyusunan silabus sebesar 75 dan penyusunan RPP sebesar 74. Sedangkan pada siklus ke 2 pertemuan ke 2 adalah, nilai rata-rata mahasiswa dalam menyusun prota sebesar 98, sedangkan prosem/promes sebesar 96, penyusunan silabus sebesar 95 dan penyusunan RPP sebesar 98. Dengan demikian proses pembelajaran pada siklus II mengalami peningkatan dan telah mencapai indikator pencapaian hasil belajar mahasiswa.

\section{PEMBAHASAN}

Berdasarkan hasil penelitian tindakan kelas dapat disimpulkan bahwa pengembangan manajemen pembelajaran berbasis daring dengan menggunakan aplikasi google classroom dapat dilakukan melalui beberapa cara yaitu: merencanakan pembelajaran daring dengan aplikasi pembelajaran daring, melaksanakan dan mengevaluasi. Pada tahap perencanaan hal-hal yang dilakukan adalah:(1) membuat email dengan gmail dulu sebagai akun untuk bisa membuat google classroom, (2) mendownload aplikasi google classroom pada play store jika menggunakan handphone, jika membuka leptop login dengan alamat www.classroom.google.com, (3) merencanakan membuat topik-topik yang aka nada pada google classroom, (4) merencanakan kontrak kuliah, RPS, dan materi perkuliahan yang akan di upload, (5) merencanakan tugas-tugas yang akan diberikan pada aha siswa, (6) merencanakan forum diskusi yang akan di bahas, (7) mrencanakan kuis yang akan diberikan melalui google classroom. Pengembangan manajemen pembelajaran berbasis daring dapat dilakukan dengan memanfaatkan learning management system (LMS) salah satunya dengan aplikasi google classroom. Pemanfaatan google classroom dapat melalui multiplatform yakni melalui komputer dan telepon genggam. Guru dan siswa dapat mengunjungi situs https://classroom.google.com atau mengunduh aplikasi melalui playstore di android atau app store di iOS dengan kata kunci google classroom (Wicaksono \& Rachmadyanti, 2017:515).

Hal tersebut senada dengan pendapat Albantani \& Rozak (2018:94) yang menyatakan mengatur perencanaan dalam google classroom dimulai dengan awal kontrak perkuliahan telah disetujui keberlangsungan pembelajaran sesuai kurikulum yang telah disetujui antara dosen dengan mahasiswa, pengunggahan materi, pemberian tugas individual secara berkelompok serta diupload secara terjadwal berarti di sini telah terlihat bahwa google classroom dapat mengorganisasikan dan menjadwalkan pengajaran perkuliahan dengan baik. 
Pada tahap pelaksanaan penggunaan aplikasi google classroom, hal-hal yang dapat dilakukan adalah melalukan komunikasi, diskusi, pemberian materi, pemberian kuis, pemberian tugas pada maha siswa melalui aplikasi google classroom. Agar tugas mahasiswa bisa tepatwaktu maka bisa mengatur due date dan end date pada penugasan (assignment), dosen bisaa memberikan komentar mengkoreksi tugas, memberikan penilaian pada tugas, jika menggunaan tablet yang ada stik untuk menulis, maka dosen bisa mencooret-coret hasil pekerjaan mahasiswa dan mengirikan kembali kepada mahasiswa. Penggunaan aplikasi ini terbukti efektif dalam meningkatkan kemampuan mahasiswa S1 PGSD FKIP UNUSA pada mata kuliah perencanaan pembelajaran, Hal tersebut dibuktikan dengan selisih nilai pada siklus 1 pertemuan ke 1 rata-rata nilai penyusunan perangkat pembelajaran SD (Prota, Prosem/Promes, Silabus, RPP) sekitar 45, sedangkan pada pertemuan ke 2 nilai rata-rata peragkat pembelajaran sekitar 68,25. Sedangkan pada siklus ke 2 pada pertemuan 1 nilai rata-rata penyusunan perangkat pembelajaran sekitar 73,5, sedangkan pada pertemuan ke 2 nilai rata-rata mahasiswa dalam penyususnan perangkat pembelajaran SD sebesar 96,75. Keefektifan mahasiswa dalam menggunakan aplikasi google classroom karena di dukung dengan kemudahan mahasiswa untuk mengirimkan tugas dan kemudahan dosen untuk langsung merespon tugas yang sudah diserahkan, mengoreksi dapat dilakukan dimana saja dan dapat langsung memberikan komentar dan nilai pada mahasiswa.

Kendala yang ditemui ketika pembelajaran menggunakan aplikasi google classroom pada saat penelitian adalah kurang aktif mahasiswa dalam merespon semua tugas yang ada pada google classrom dengan alasan sinyal, sehingga banyak tugas yang belum tuntas dikerjakan mahasiswa. Untuk mengatasi permasalahan tersebut dilakukan dengan mengingatkan pada mahasiswa jika ada tugas di google classroom dan memberikan batas waktu pengumpulan tugas dengan mengatur waktu end date pada aplikasi google classroom.

Peningkatan kualitas pembelajaran ditentukan kesuksesan guru atau dosen dalam mengelola pembelajaran di kelas... learning quality is determined by the success of a teacher in managing in-classroom learning (Nafiah et al., 2019:1261). Penggunaan google classroom dalam memanajemen pembelajaran dapat meningkatkan kemampuan mahasiswa dalam menyusun perangkat pembelajaran. Kegiatan pembelajaran yang dilakukan dapat berhasil dan sukses karena telah di kelola dengan baik.

Pembelajaran dengan menggunakan Google Classroom memiliki keefektifan dalam proses pembelajaran (Maharani \& Kartini, 2019:171). Keefektifan pembelajaran dengan menggunakan Google Classroom dapat dilihat berdasarkan tingkat kesalahan yang dibuat oleh mahasiswa saat menyelesaikan permasalahan yang diberikan, keefektifan pembelajaran juga dapat dilihat berdasarkan ketepatan waktu yang dipergunakan oleh mahasiswa untuk belajar, mengunggah hasil tes serta mengunggah hasil kuesioner melalui kelas Google Classroom.

Dengan penggunaan google classroom mahasiswa dan dosen akan akan terlibat secara aktif dalam kegiatan pembelajaran dimanapun berada. Menurut Kurniawan (2016:65) penerapan google classroom juga memberikan pengalaman belajar yang lebih luas kepada mahasiswa, dengan berbantuan google classroom mahasiswa dapat terlibat secara aktif dalam kegiatan diskusi, mengembangkan ide, memperkaya materi, terbisaa menyeleasaikan kuis, dan lain-lain dan juga pengalaman belajar mereka memberikan 
dorongan kepada mahasiswa untuk terus belajar dan meningkatkan kemampuan pemecahan masalahnya.

Pengunggahan jawaban ujian bisaanya sudah tertera pada room ujian tersebut, dan tidak boleh melebihi batas akhir pengunggahan jawaban ujian (Albantani \& Rozak, 2018:94). Hal tersebut dapat dilakukan pada kegiatan evaluasi perkuliahan. Pelaksanaan evaluasi perkuliahan bisa dilakukan dengan membuat kuis, mengerjakan pertanyaan uraian, mengerjakan tugas. Google classroom dapat mengevaluasi siswa dari berbagai test. Contohnya mahasiswa akan mengikuti ujian melalui aplikasi ini, maksudnya adalah bahwa teks ujian tersebut sudah disediakan oleh dosen dalam google classroom, mahasiswa mengerjakannya lalu diupload di room ujian yang sudah tertera di aplikasi ini.

Dengan meminta mahasiswa menjawab soal yang ada pada google classroom, atau menjawab kuis maka kita akan lebih mudah untuk memberikan penilaain, dan mahasiswa yang belum mengumpulkan juga ada terlihat dengan mudah, jika mahasiswa sudah megumpulkan ujian atau tugas, maka aka nada tanda hijau bertuliskan "turned in" sedangkan yang belum mengumpulkan akan terlihat tulisan "assigned". Dengan demikian pengunaan aplikasi google classromsangat efektif dalam melakukan evaluasi pada mata kuliah perencanaan embelajaran prodi S1 PGSD FKIP UNUSA. Manajemen pembelajaran daring yang tepat dan pemanfaatan teknologi dalam pembelajaran untuk dapat meningkatkan kualitas Pendidikan bagi calon guru PGSD.

\section{SIMPULAN DAN SARAN}

Penerapan manajemen pembelajaran berbasis daring dengan menggunakan aplikasi google classroom untuk meningkatkan kemampuan mahasiswa dalam membuat perangkat pembelajaran pada mata kuliah perencanaan pembelajaran di Prodi S1 PGSD FKIP UNUSA dilakukan dengan: 1) merencanakan pembelajaran dengan menggunakan aplikasi google classroom, 2) melaksanakan pembelajaran dengan cara mengupload materi yang akan disamapaikan pada mahasiswa, memberikan penugasan pada mahasiswa berupa membuat perangkat pembelajaran SD yaitu program tahunan (prota), program semester (prosem /promes), silabus tematik SD, rencana pelaksanaan pembelajaran (RPP) tematik SD, dan 3) mengevaluasi matakuliah perencanaan pembelajaran mealui google classroom dengan memberikan tugas untuk mengunggah seluruh perangkat pembelajaran yang sudah diperbaiki dengn membuat room untuk tugas ujian tengah semester (UTS) pada mahasiswa. Berdasarkan hasil penerapan manajemen pembelajaran berbasis daring dengan menggunakan aplikasi google classroom pada mata kuliah perencanaan pembelajaran prodi S1 PGSD FKIP UNUSA terbukti sangat efektif meningkatkan kemampuan mahasiswa dalam menyusun perangkat pembelajaran SD. Hal tersebut dilihat dari kenaikan setiap siklus dan nilai rata-rata mahasiswa lebih dari kriteria ketercapaian indikator yang ditentukan. Pada siklus 1 pertemuan ke 1 rata-rata nilai penyusunan perangkat pembelajaran SD (Prota, Prosem/Promes, Silabus, RPP) sekitar 45, sedangkan pada pertemuan ke 2 nilai rata-rata peragkat pembelajaran sekitar 68,25. Sedangkan pada siklus ke 2 pada pertemuan 1 nilai rata-rata penyusunan perangkat pembelajaran sekitar 73,5, sedangkan pada pertemuan ke 2 nilai rata-rata mahasiswa dalam penyususnan perangkat pembelajaran SD sebesar 96,75 
Hal -hal yang perlu disarankan pada penelitaian ini adalah sebagai berikut: Bagi prodi S1 PGSD FKIP UNUSA disarankan untuk semua mata kuliah bisa menggunakan google classroom agar perkuliahan bisa berlngsung efektif dan efesien. Bagi peneliti lain untuk mengembangkan penelitian sejenis terkait manajemen pembelajaran berbasis daring dengan menggunakan aplikasi yang lain atau mengembangkan lagi google classroom dengan dimodivikasi dengan aplikasi yang lain untuk penelitian yang lebih lanjut.

\section{DAFTAR RUJUKAN}

Albantani, A. M., \& Rozak, A. (2018). Desain perkuliahan bahasa arab melalui google classroom.

Al-Maroof, R. A. S., \& Al-Emran, M. (2018). Students Acceptance of Google Classroom: An Exploratory Study using PLS-SEM Approach. International Journal of Emerging Technologies in Learning, 13(6).

Creswell, J. W. (2012). Educational Research (Fourth). United States of America: Pearson.

Maharani, N., \& Kartini, K. S. (2019). Penggunaan google classroom sebagai pengembangan kelas virtual dalam keterampilan pemecahan masalah topik kinematika pada mahasiswa jurusan sistem komputer. PENDIPA Journal of Science Education, 3(3), 167-173.

Majid, A. (2008). Perencanaan Pembelajaran. Bandung: Remaja Rosydakarya.

Meenakumari, D. J., \& Antony, B. (2013). Assessing the essential features of ICT-based LMS for performance enhancement. IRACST-International Journal of Research in Management \& Technology (IJRMT), ISSN, 2249-9563.

Nadlir, M. (2013). Perencanaan pembelajaran berbasis karakter. Jurnal Pendidikan Agama Islam (Journal of Islamic Education Studies), 1(2), 338-352.

Nafiah. (2017). Manajemen Pendidikan. Surabaya: Unusa Press.

Nafiah, N. (2017). Manajemen Pembelajaran Tematık Integratıf Sesua1 Kurıkulum 2013 Pada Kelas 4 SD Khadijah Surabaya. Education and Human Development Journal, 2(1). https://doi.org/10.33086/ehdj.v2i1.385

Nafiah, N., Bafadal, I., Supriyanto, A., \& Arifin, I. (2019). Artistic Supervision Model Development for Improved Pedagogic Competence of Primary School Teachers. Illkögretim Online, 18(3). https://doi.org/10.17051/ilkonline.2019.612140

Pratomo, Y. (2019, 05). APJII: Jumlah Pengguna Internet di Indonesia Tembus 171 Juta Jiwa.https://tekno.kompas.com/read/2019/05/16/03260037/apjii-jumlahpengguna-internet-di-indonesia-tembus-171-juta-jiwa.

Putri, G. K., \& Dewi, Y. A. S. (2019). Pengaruh Model Pembelajaran Jarak Jauh Berbasis Google Classroom. AL-FIKRAH, 2(1), 60-79.

Sholeh, M. (2007). Perencanaan pembelajaran mata pelajaran geografi tingkat SMA dalam konteks KTSP. Jurnal Geografi: Media Informasi Pengembangan Dan Profesi Kegeografian, 4(2).

Uno, H. B. (2008). Perencanaan pembelajaran (Vol. 61). Jakarta: Bumi Aksara.

Wicaksono, V. D., \& Rachmadyanti, P. (2017). Pembelajaran blended learning melalui google classroom di sekolah dasar.

Yamin, M., \& Maisah. (2012). Manajemen pembelajaran kelas. Jakarta: Gaung Persada (GP Press). 